\title{
Agronomic aspects of two Physalis species as a function of Nitrogen fertilization
}

Douglas Junior Bertoncelli', Marisa de Cacia Oliveira², Amanda Izabel dos Passos², Taylon Henrique Casagrande ${ }^{3}$, Ana Claudia Ariati ${ }^{2}$

'Universidade Estadual de Londrina, Londrina, PR, Brazil.

2Universidade Técnologica Federal do Paraná, Pato Branco, PR, Brazil.

3Universidade Estadual de Maringá, Maringá, PR, Brazil.

*Corresponding author, e-mail: dj_bertoncelli@hotmail.com

\begin{abstract}
The cultivation of small fruits has been increasing with good economic returns, and among these, the genus Physalis has been an important alternative source of income due to the high value and possibility of cultivation in small areas. However, there is not established fertilization for this crop and considering that nitrogen is one of the most limiting nutrients for the growth and development of plants, this study aimed to evaluate the agronomic aspects of two species of Physalis submitted to different $\mathrm{N}$ doses. The experiment was conducted in a greenhouse in a completely randomized design, using two species (Physalis pubescens and $P$. peruviana) and five $\mathrm{N}$ doses $\left(0,200,250,300\right.$ and $\left.350 \mathrm{~kg} \mathrm{ha}^{-1}\right)$, and seven replications. The plant height, dry mass of aerial part and roots, the number of branches, root length, yield and average fruit mass were evaluated. In these experimental conditions, it was observed that for $P$. peruviana the dose of $250 \mathrm{~kg} \mathrm{ha}^{-1} \mathrm{~N}$ resulted in a greater yield of fruit per plant, as for $P$. pubescens the dose of $350 \mathrm{~kg}$ $\mathrm{ha}^{-1} \mathrm{~N}$ showed a more efficient performance.
\end{abstract}

Keywords: fertilization, camapu, nitrogen

\section{Introduction}

The genus Physalis belong to the Solanaceae family, with about 120 species widely distributed in different regions of the world (Li et al., 2008), and according to Whitson (2012), Mexico seems to be the center of diversity of this genus. The name Physalis comes from the Greek word "physa" which means bubble or balloon, referring to the calyx that surrounds the fruit of this plant (Rufato et al., 2008). It is the genus of great prominence in the family, due to the production of polyoxygenated metabolites, withasteroids, among them the Physalins, which are substances that have presented significant pharmacological activities (Tomassini et al., 2000; Soares et al.,
2006; Damu et al., 2007; Reyes-Reyes et al., 2013), as well as carotenoids, polyphenols, vitamin C and total soluble solids in its fruits (El- Sheikha et al., 2008; Hassanien, 2011).

Among the various Physalis species, $P$. peruviana stands out due to its commercial importance, mainly in Colombia, which is one of the largest producers of this fruit (Chaves et al., 2005). In Brazil there are some production areas in Minas Gerais, Santa Catarina and Rio Grande do Sul states, however, the production is not sufficient to supply the domestic consumer market (Rodrigues et al., 2009), where the most of the fruits marketed are still imported from Colombia. 
P. pubescens L. is a sub-bush with 30 $\mathrm{cm}$ height, being able to reach up to $1,5 \mathrm{~m}$ and is considered, in most regions of Brazil, as a weed species (Lorenzi, 2008), which seems to have influence on the ignorance of its qualities for cultivation and consumption (Erasmo et al., 2004), being a species of wide distribution, found in several parts of the world.

One of the most limiting nutrients for plant development, in general, is nitrogen since it is present in the composition of amino acids and, consequently, of proteins and chlorophyll molecules. Therefore, it is related to the photosynthetic capacity of plants, and finally, to the plant growth and production, so both excess and deficiency compromising the final production (Alvarenga, 2004).

Although there are several studies with Physalis, the majority refers to the Physalins and pharmacological potential of these compounds. Studies related to nutritional management are scarce, with a few studies in $P$. peruviana (Rufato et al., 2008; El-Tohamy et al., 2009; Muniz et al., 2011) and only one about P. pubescens responses submitted to fertilization with tanned corral manure (Peixoto et al., 2010). This last one is still little known and due to its condition of weed did not arouse, until some time ago, the interest in its study. The recommendations for cultivating the crop are the same as for the tomato crop, but with some adaptations (Rufato et al., 2008).

Therefore, the aim of this study was to evaluate the agronomic aspects (growth, development, and yield) of $P$. peruviana and $P$. pubescens plants submitted to different doses of nitrogen in order to establish more appropriate levels according to the obtained responses.

\section{Materials and Methods}

The seedlings of the two species -

Physalis pubescens and $P$. peruviana - were obtained through seeds from plants located at UTFPR, Paraná state, cultivated in the field and in a greenhouse. The sowing was carried out in expanded polystyrene trays, with 72 cells, containing fertile humus as a substrate, where 3 seeds per cell were placed. The thinning was performed at 20 days after sowing, remaining the most vigorous seedlings. The trays were kept in a greenhouse, under the same conditions of the experiment, and the irrigation was performed manually, as needed. The seedlings were transplanted to pots at 70 days after sowing (approximately $15 \mathrm{~cm}$ high). The soil used was a Latossolo Vermelho Distroférrico or an Ustox (American Classification Soil Taxonomy) with the following attributes: organic matter content - 60,31 g. $\mathrm{dm}^{-3}$, phosphorus - 3,46 mg. $\mathrm{dm}^{-3}$, potassium - 0,4 $\mathrm{cmol}_{\mathrm{c}} \mathrm{dm}^{-3}$, calcium - 4,86 $\mathrm{cmol}_{c} \mathrm{dm}^{-3}$, magnesium - 2,10 $\mathrm{cmol}_{c} \mathrm{dm}^{-3}$, basis saturation $74,2 \%$ and $\mathrm{pH} \mathrm{4,6}$. The soil was corrected using a calcitic limestone in order to reach $\mathrm{pH}$ equal to 5.7, which is within the range in which the availability of nitrogen, phosphorus, and potassium is considered adequate (Taiz \& Zeiger, 2010)

The experiment was conducted in 5 $L$ pots that were kept in a greenhouse under controlled conditions. The treatments consisted of five $\mathrm{N}$ doses which were: 0, 200, 250, 300 and $350 \mathrm{~kg} \mathrm{ha}{ }^{-1}$, whereby applied in the form of urea, divided into four fortnightly applications. The doses of phosphorus (600 kg ha-1) and potassium (500 kg ha-1) were applied in a single dose at the time of transplanting according to the recommendations for tomato crop (Filgueira, 2008). The plants were irrigated daily by sprinkling, in the morning and late afternoon, keeping the soil moisture at the field capacity. When the plants reached a stage where the leaves prevented the soil proper irrigation in the pots, the irrigation was changed to be performed manually. The average daily temperature during the experiment period (February to October 2012) was approximately $28^{\circ} \mathrm{C}$.

The plant height (main branch), the number of branches, yield per plant (mass) and the average mass of the fruits were evaluated. These last two variables were evaluated during five weeks. At the end of the experiment dry and fresh mass of aerial part and roots, and root length were determined. Seven plants were used in each treatment for the evaluations, each consisting of one replicate.

It was also calculated the relative increase in yield from nitrogen fertilization (RIYNF). For this, the difference between the maximum fruit yield (MY), in $\mathrm{kg} \mathrm{ha}^{-1}$, and the fruit yield in 
the zero dose (FY zero), divided by the dose of $\mathrm{N}$ required to obtain $M Y$, was used, demonstrated by the following equation: (MY - FT zero) / (MY dose) (Ferreira et al., 2010). The highest yield at the different $\mathrm{N}$ doses was taken into account, correlating with the yield at the control treatment (without fertilization).

The experiment was carried out in a completely randomized design with two species, five treatments, and seven replicates, in a $2 \times 5$ factorial scheme, and the regression analyses were performed using ASSISTAT statistical program (Silva \& Azevedo, 2002).

\section{Results and Discussion}

As expected, both species of Physalis responded positively to the $\mathrm{N}$ increment. Regarding the plant height as a function of the $\mathrm{N}$ doses, P. pubescens showed better results than P. peruviana (Figure 1). El-Tohamy et al. (2009) studying $P$. peruviana in a sandy soil, observed that the increase of $\mathrm{N}$ doses (50 to $200 \mathrm{~kg} \mathrm{ha}^{-1}$ ) resulted in increased plant height, in which 200 $\mathrm{kg} \mathrm{ha}^{-1}$ resulted in the highest plant height ( 88.25 $\mathrm{cm}$ ).

In the present study, however, under different conditions than those obtained by ElTohamy et al. (2009), the plants of P. peruviana and P. pubescens exceeded the values of 140 and $170 \mathrm{~cm}$ (Figure 1), respectively, with $350 \mathrm{kha}-1$ of $\mathrm{N}$. The same was observed in cotton crop, with $\mathrm{N}$ levels varying from 60 to $180 \mathrm{~kg}$ ha-1, obtaining higher plants in response to increased nitrogen fertilization (Teixeira et al., 2008). These results confirm the importance of this macronutrient in the growth, resulting in higher plants.

The plant dry mass was influenced by $N$ doses, however, it did not show a significant difference between the species (Figure 2A). P. pubescens showed dry mass slightly greater than $P$. pubescens. In an experiment with P. peruviana, nitrogen fertilization also positively influenced the plant mass (fresh), reaching $846.25 \mathrm{~g}$ per plant in $200 \mathrm{~kg} \mathrm{ha}^{-1}$ of $\mathrm{N}$ and $274.25 \mathrm{~g}$ per plant in $50 \mathrm{~kg}$ $\mathrm{ha}^{-1}$ of $\mathrm{N}$ (Tohamy et al., 2009). Sant'Ana \& Silveira (2008) studying the common bean crop cycle described the influence of doses of nitrogen topdressing in the development of the seedlings, and found that the best dose was $120 \mathrm{~kg} \mathrm{ha}^{-1}$ of $\mathrm{N}$.

The increase in mass was also observed in cauliflower as a function of $\mathrm{N}$ doses (Kano et al., 2010), however, Aratani et al. (2006) could not relate the dry mass to the nitrogen top-dressing in corn crop.

The number of branches showed a linear increase for both species (Figure 2B). In this case, $P$. peruviana showed higher values, probably

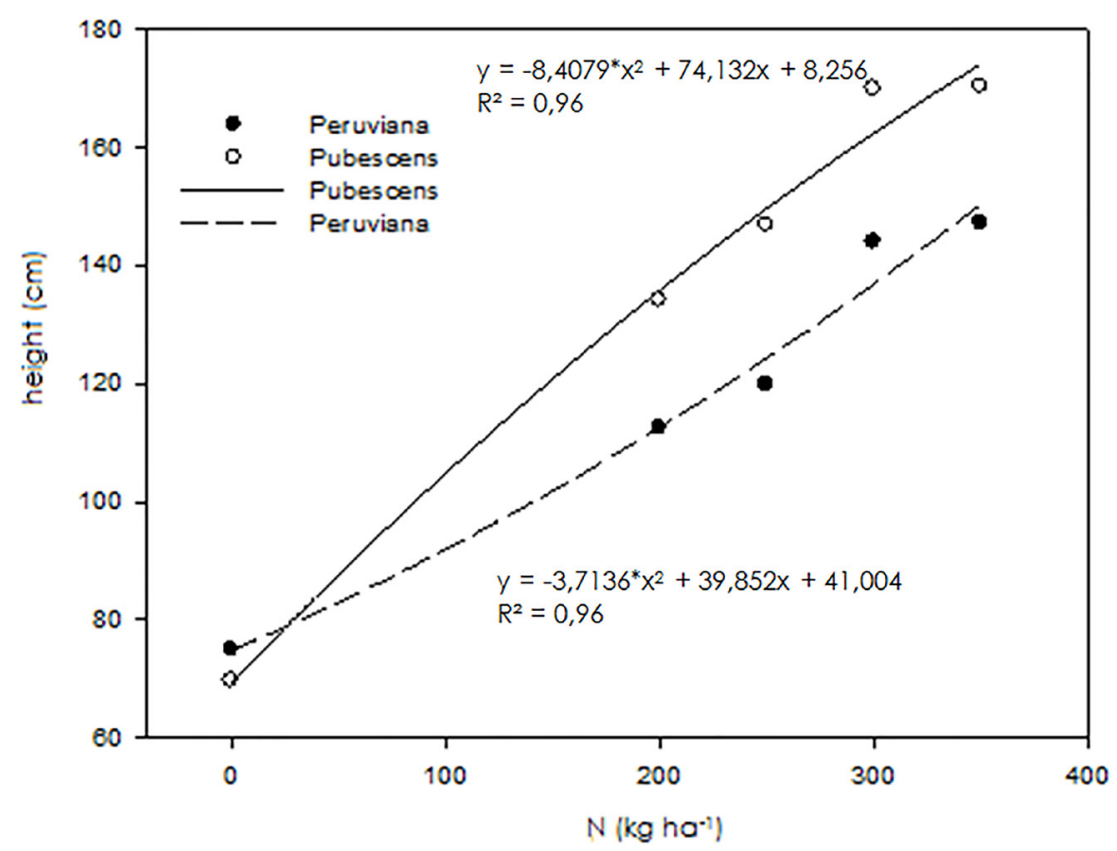

Figure 1. The final height of $P$. pubescens and $P$. peruviana plants submitted to $N$ doses. Pato Branco county, UTFPR, 2012. 
because it is characteristic of this species since it was found by El-Tohamy et al. (2009) who observed an increase in the number of branches from 11.75 to 16.25 branches per plant as far as the $\mathrm{N}$ doses increased
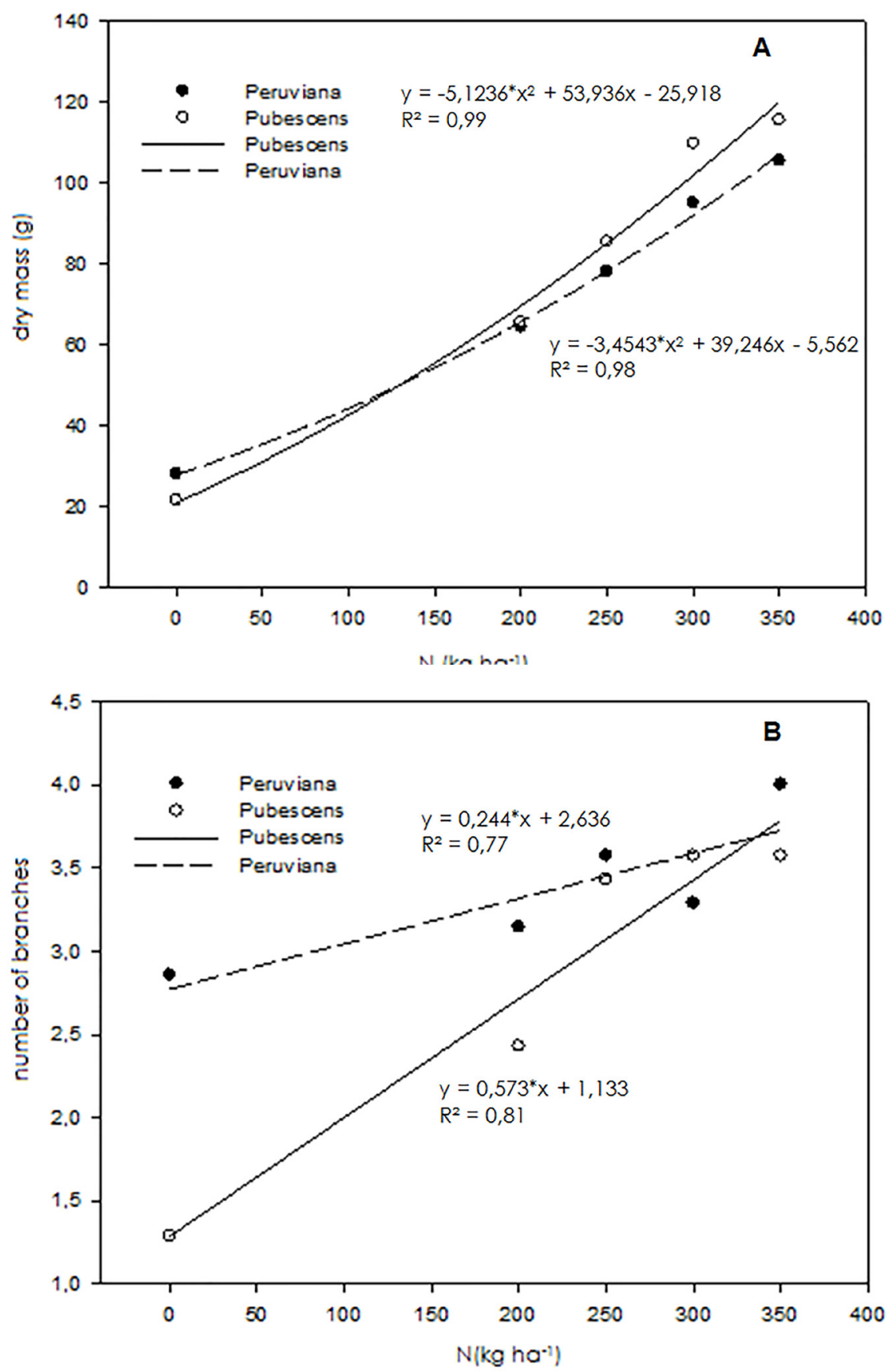

Figure 2. Plant dry mass (g) (A) and the number of branches per plants (B) in $P$. pubescens and $P$. peruviana, submitted to different doses of N. Pato Branco county, UTFPR, 2012.

Therefore, the process of issuing branches may be more related to genetic characteristics than to nutrient supply, however, emphasizing that nutrient supply is essential for the expression of the entire genetic potential of the species.

As in the aerial part, nitrogen also showed a positive influence on the roots, both in length (Figure 3A) and in dry mass (Figure 3B), and the root length showed a linear response for the species, however, $P$. pubescens showed a better response to $\mathrm{N}$ doses.

Mendonça et al. (2006) working with different doses of $\mathrm{N}$ and phosphate, in papaya plants, also obtained an increase in root length 
with nitrogen fertilization, and the highest length $\quad\left(1,545 \mathrm{~g} \mathrm{~N} \mathrm{dm}^{-3}\right)$. $(14.35 \mathrm{~cm})$ was observed at the maximum dose
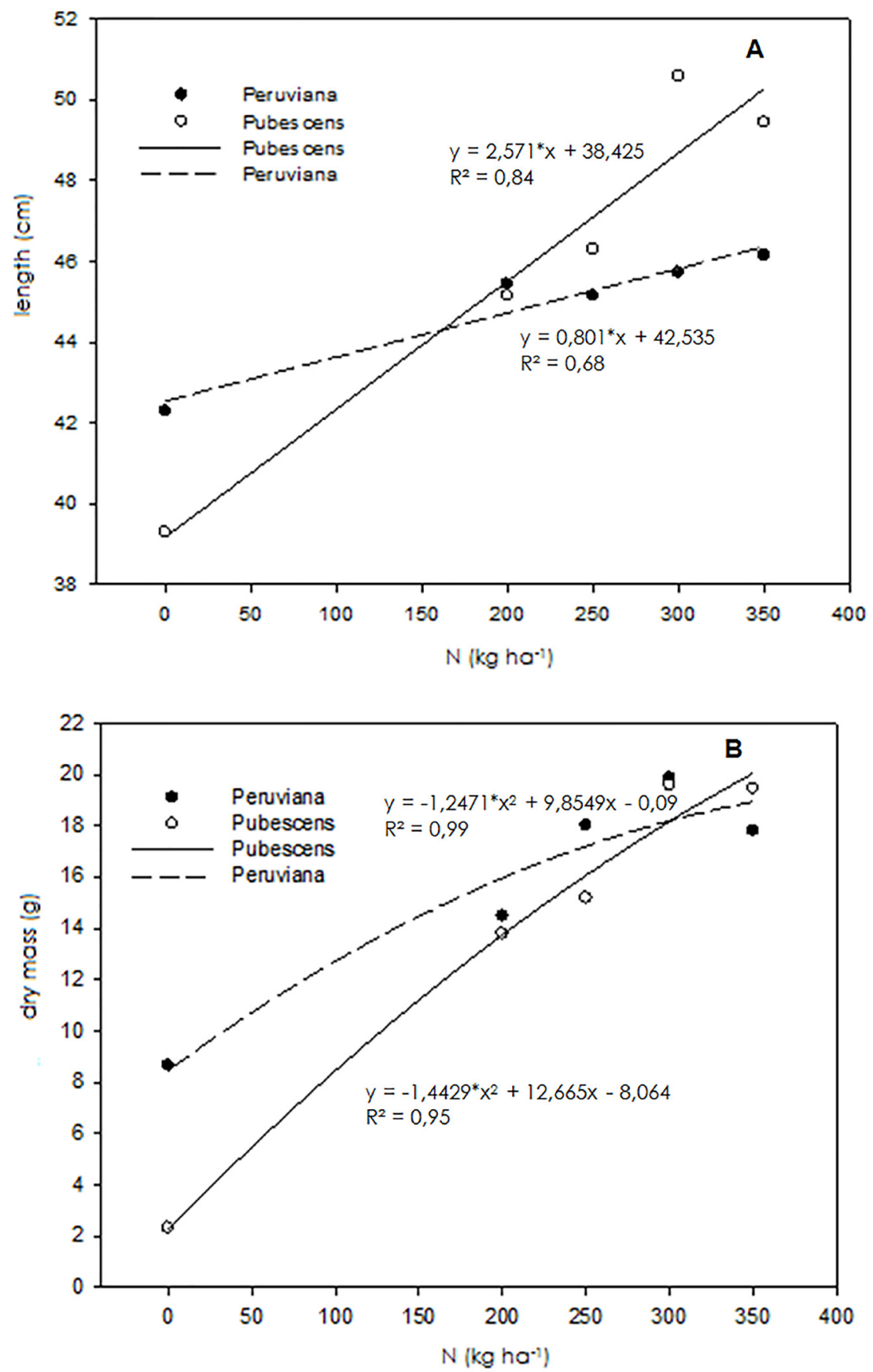

Figure 3. Average length (A) and root dry mass (B) in $P$. pubescens and $P$. peruviana plants, submitted to different doses of N. Pato Branco county, UTFPR, 2012.

Both species showed a quadratic response to $\mathrm{N}$ doses for the root dry mass (Figure 3B). In Tamarind plants, the highest values of root dry mass resulted from phosphate fertilization $(5$ $\mathrm{kg} \mathrm{m}^{-3}$ ) in the absence of $\mathrm{N}$ and with $10 \mathrm{~kg} \mathrm{~m}^{-3}$ of phosphorus combined with $1.6 \mathrm{~kg} \mathrm{~m}^{-3}$ of $\mathrm{N}$ (Souza et al. , 2007). As for yellow passion fruit, the responses showed a linear model, with the best result ( $6.23 \mathrm{~g}$ dry mass) at the dose of $3.2 \mathrm{~g}$ $\mathrm{N} \mathrm{dm}^{-3}$ (Mendonça et al., 2007). Damasceno et al. (2011) verified an increase in the fresh mass of beet roots as a function of nitrogen fertilization, with the highest value (199.95 g) found at the 300 $\mathrm{kg} \mathrm{ha}^{-1} \mathrm{~N}$ dose.

Regarding fruit yield per plant, it can be verified that the highest $N$ doses used in the 
experiment were only favorable to P. pubescens, whereas $P$. peruviana showed a decrease in fruit yield and mass in the $350 \mathrm{~kg} \mathrm{ha}^{-1}$ of $\mathrm{N}$ dose (Figure 4A and B). El-Tohamy et al. (2009) obtained a total production per plant of $472.50 \mathrm{~g}$ with the dose of $200 \mathrm{~kg} \mathrm{ha}^{-1}$ and $159.19 \mathrm{~g}$ with the $50 \mathrm{~kg}$ ha-1 $\mathrm{N}$ dose.
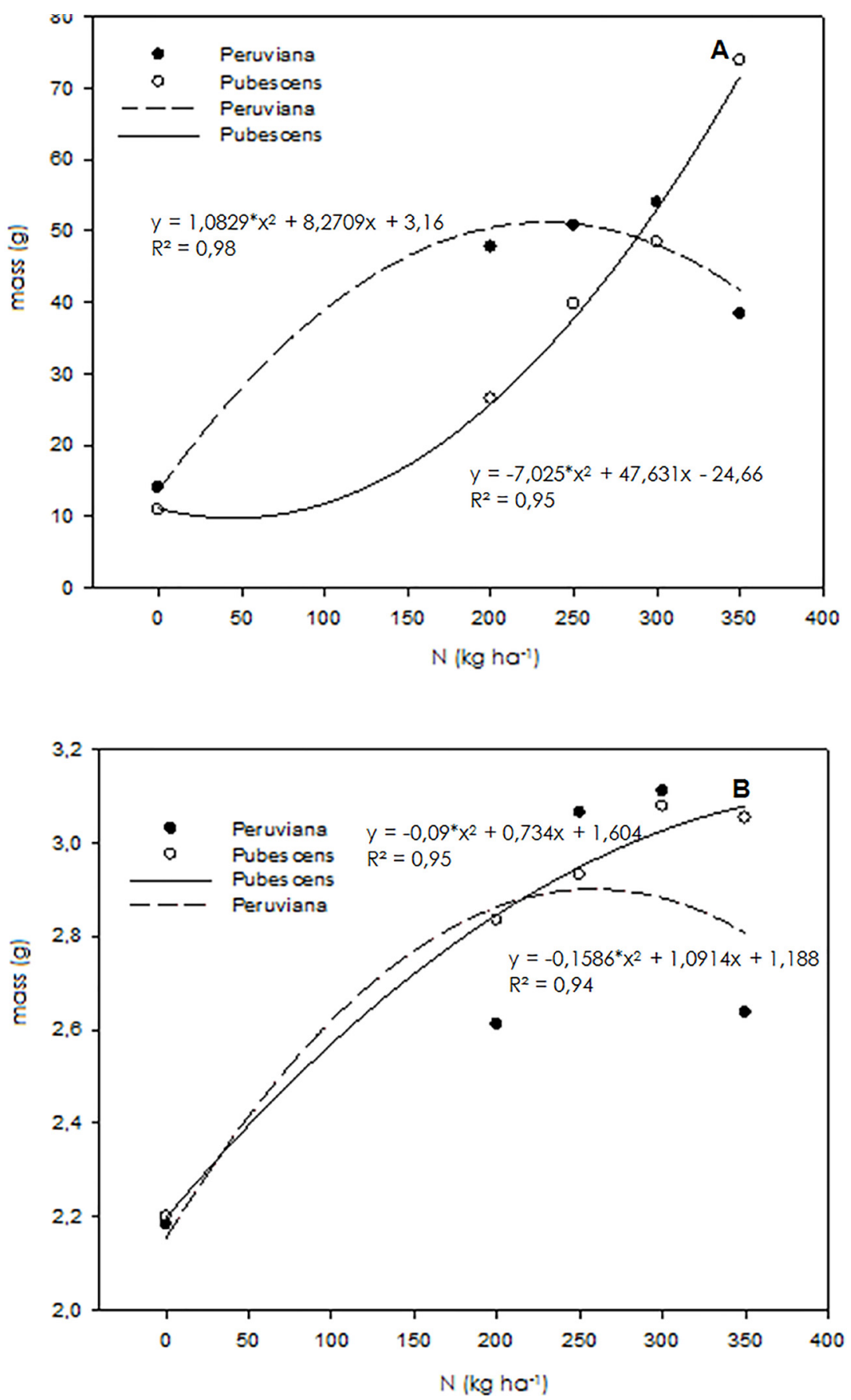

Figure 4. Average yield of fruits per plant (A) and average mass of fruits (B) in $P$. pubescens and P. peruviana plants, submitted to different doses of N. Pato Branco county, UTFPR, 2012.

In the present work, $P$. pubescens responded better to $N$ increases, possibly due to its rusticity and in addition to it has not yet undergone any selection process, unlike $P$. peruviana, which is the most cultivated species, then tends to have plants selected by farmers, according to their production capacity. Excess $\mathrm{N}$ can cause nutritional imbalance and affect crop yield, which was observed in the yield of P. peruviana (Figure 4A) with $\mathrm{N}$ dose of $350 \mathrm{~kg}$ $\mathrm{ha}^{-1}$. Physiologically, this may have occurred due to redistribution of photoassimilates to other 
vegetative parts of the plants.

Morales et al. (2012) found that in strawberries there was a decrease in yield in some cultivars and an increase in the number of stolons in the plants with higher $\mathrm{N}$ content, while others (cultivars) in the same experiment showed increased yield as a function of increased nitrogen fertilization, showing that varied responses occur in different varieties of the same species.

In the evaluation of fruit mass, $\mathrm{N}$ doses also showed influence, and as it happened with the yield, $P$. peruviana showed fruits with smaller masses with a dose of $350 \mathrm{~kg} \mathrm{ha}^{-1}$, and $P$. pubescens responding better to the increase of $\mathrm{N}$ ( Figure 4B). In an experiment developed by Roy et al. (2011) with bell pepper plants, the authors obtained an increase in fruit yield per plant, as well as in the fruit mass, as a function of increase $\mathrm{N}$ doses, the same observed in $\mathrm{P}$. pubescens, in the present work. According to Campos et al. (2008), the increase in the number of fruits per plant, in bell peppers, with an elevation of $\mathrm{N}$ doses is probably due to the fact that $N$ is the element absorbed in greater quantity and with a fundamental importance for the growth and development of bell pepper plants. Although plants of the same family have similar nutritional requirements, it is not possible to generalize and, thus, is important determining the needs for each species, if not for each variety (cultivar).

For the RIYNF, the results obtained were $1.78 \mathrm{~kg}$ of fruits per $\mathrm{kg}$ of $\mathrm{N}$ for $P$. pubescens and $1.33 \mathrm{~kg}$ of fruits per $\mathrm{kg}$ of $\mathrm{N}$ for $P$. peruviana. For the genus Physalis, there are still no ideal values established, however, $P$. pubescens showed higher relative efficiency in the nitrogen utilization, as the results showed. Ferreira et al. (2010), working with tomato crop, found indexes of 15.23 and $13.22 \mathrm{~kg}$ of fruits per $\mathrm{kg}$ of $\mathrm{N}$ for tomatoes grown in spring/summer with different doses of $\mathrm{N}$ and of 22.90 and $27.67 \mathrm{~kg}$ of fruits per $\mathrm{kg}$ of $\mathrm{N}$ for tomatoes cultivated in fall/spring. The authors argued that these values are low for the crop, however, probably the low efficiency in $\mathrm{N}$ utilization was due to high rainfall in the first growing season and in the irrigation type in the second growing season (furrow irrigation) which may have caused leaching of the $\mathrm{N}$ applied. Regarding Physalis, these values are only illustrative, since it is not possible to state whether they are considered ideal or not based on this first attempt to use this expression.

The different Physalis responses, in terms of fruit yield, in different doses of $\mathrm{N}$, may be related to selection processes, since domesticated plants, such as $P$. peruviana, lose their rusticity by being constantly selected, and are much more dependent on human alterations and interventions in its environment (Veasey et al., 2011 ). Probably, the plants of this species already have a higher initial productive potential, thus, it is closer to its limit, with greater response in lower doses of nutrients and the negative effect with increase of fertilization, whereas $P$. pubescens still has all its potential to be explored, which can be observed by the positive responses in all analyzed variables.

\section{Conclusions}

The nitrogen doses used in this study resulted in increased in the number of branches, plant height, root length, as well as the dry mass of root and aerial part, fruit mass and yield in both species of Physalis.

Under the conditions tested, it was observed that for $P$. peruviana, the dose of 250 $\mathrm{kg} \mathrm{ha}^{-1}$ of $\mathrm{N}$ resulted in a higher fruit yield per plant, whereas for $P$. pubescens the dose of 350 $\mathrm{kg} \mathrm{ha}^{-1}$ of $\mathrm{N}$ was more efficient.

\section{Acknowledgments}

To Araucária Foundation by the financial support and to $\mathrm{CNPa}$ by granting a master degree scholarship.

\section{References}

Alvarenga, M.A.R. 2004. Tomate: Produção em campo, em casa de vegetação e em hidroponia. UFLA, Lavras, Brasil. 393p.

Aratani, R.G., Fernandes, F.M., Mello, L.M.M. 2006. Adubação nitrogenada de cobertura na cultura do milho irrigado, em sistema plantio direto. Revista Científica Eletrônica de Agronomia 9: 1-10.

Campos, V.B., Oliveira, A.P., Cavalcante, L.F., Prazeres, S.S. 2008. Rendimento do pimentão submetido ao nitrogênio aplicado via água de irrigação em ambiente protegido. Revista de Biologia e Ciências da Terra 8: 72-79.

Chaves, A.C., Schuch, M.W., Erig, A.C. 2005. Estabelecimento e multiplicação in vitro 
de Physalis peruviana L. Revista Ciência e Agrotecnologia 29: 1281-1287.

Damasceno, L.A., Guimarães, M.A., Guimarães, A.R. 2011. Produtividade de beterraba em função de doses de nitrogênio. Horticultura Brasileira 29: S3694-S3701. (Suplemento CD-ROM).

Damu, A.G., Kuo, P.-C., SU, C.-R., KUo, T.-H., Chen, T.-H., Bastow, K.F., Lee, K.-H., Wu, T.S. 2007. Isolation, structures, and structuresytotoxic activity relationships of withanolides and physalins from Physalis angulata. Journal of Natural Products 70: 1146-1152.

El-Sheikha, A.F., Zaki, M., Bakr, A., El Habashy, M., Montet, D. 2008. Physico-chemical properties and biochemical composition of Physalis (Physalis pubescens L.) fruits. Food 2: 124-130.

El-Tohamy, W.A., El-Abagy, H.M., Abou-Hussein, S.D., Gruda, N. 2009. Response of cape gooseberry (Physalis peruviana L.) to nitrogen application under sandy soil conditions. Gesunde Pflanzen 61: 123-127.

Erasmo, E.A.L., Pinheiro, L.L.A., Costa, N.V. 2004. Levantamento fitossociológico das comunidades de plantas infestantes em áreas de produção de arroz irrigado cultivado sob diferentes sistemas de manejo. Planta Daninha 22: 195-201.

Ferreira, M.M.M., Ferreira, G.B., Fontes, P.C.R. 2010. Eficiência da adubação nitrogenada do tomateiro em duas épocas de cultivo. Revista Ceres 57: 263-273.

Filgueira, F.A.R. 2008. Novo manual de olericultura. $3^{\mathrm{a}}$ ed. Editora UFV, Viçosa, Brasil. $421 \mathrm{p}$.

Hassanien, M.F.R. 2011. Physalis peruviana: a rich source of bioactive phytochemicals for functional foods and pharmaceuticals. Food Reviews International 27: 259-273.

Kano, C., Salata, A.C., Higuti, A.R.O., Godoy, A.R., Cardoso, A.I.I., Evangelista, R.M. 2010. Produção e qualidade de couve-flor cultivar Teresópolis gigante em função de doses de nitrogênio. Horticultura Brasileira 28: 453-457.

Li, Y.Z., Pan, Y.M., Huang, X.Y., Wang, H.S. 2008. Withanolides from Physalis alkekengi var. francheti. Helvetica Chimica Acta 91: 2284-2291.

Lorenzi, H. 2008. Plantas daninhas do Brasil. Plantarum, Nova Odessa, Brasil. 672p.

Mendonça, V., Ferreira, E.A., Paula, Y.C.M., Batista, T.M.V., Ramos, J.D. 2007. Crescimento de mudas de maracujazeiro amarelo influenciado por doses de nitrogênio e de superfosfato simples. Caatinga 20: 137-143.

Mendonça, V., Pedrosa, C., Feldberg, N.P.,
Abreu, N.A.A., Brito, A.P.F., Ramos, J.D. 2006. Doses de nitrogênio e superfosfato simples no crescimento de mudas de mamoeiro "formosa". Ciência e Agrotecnologia 30: 1065-1070.

Morales, R.G.F., Faria, M.V., Resende, J.T.V., Rissini, A.L.L., Carminatti, R., Faria, C.M.D.R. 2012. Produtividade do morangueiro em função da adubação orgânica complementar em cultivo protegido. Ambiência 8: 23-33.

Muniz, J., Kretzschmar, A.A., Rufato, L., Silveira, F.N., Brighenti, L.M., Sabatino, R.S. 2011. Plantas de fisális (Physalis peruviana L.) submetidas à adubação química e orgânica. Cadernos de Agroecologia 6: 1-5.

Peixoto, N., Peixoto, F.C., Vaz, U.L., Neri, S.C.M., Monteiro, J.G. 2010. Adubação orgânica e cobertura do solo no crescimento e produção de camapu. Horticultura Brasileira 28: 370-372.

Reyes-Reyes, E.M., Jin, Z., Vaisberg, A.J., Hammond, G.B., Bates, P.J. 2013. Physangulidine A, a withanolide from Physalis angulata, perturbs the cell cycle and induces cell death by apoptosis in prostate cancer cells. Journal of Natural Products 76: 2-7.

Rodrigues, E., Rockenbach, I.I., Cataneo, C., Gonzaga, L.V., Chaves, E.S., Fett, R. 2009. Minerals and essential fatty acids of the exotic fruit Physalis peruviana L. Ciência e Tecnologia de Alimentos 29: 642-645.

Roy, S.S., Khan, M.S.I., Pall, K.K. 2011 . Nitrogen and phosphorus efficiency on the fruit size and yield of Capsicum. Journal of Experimental Sciences 2: 32-37.

Rufato, L., Rufato, A.R., Schlemper, C., Lima, C.S.M., Kretzschmar, A.A. 2008. Aspectos técnicos da cultura da physalis. UDESC, Pelotas, Brasil. 100p.

Sant'Ana, E.V.P., Silveira, P.M. 2008. Crescimento do feijoeiro (Phaseolus vulgaris L.) influenciado por doses de nitrogênio em cobertura. Pesquisa Agropecuária Tropical 38: 134-140.

Silva, F.A.S., Azevedo, C.A.V. 2002. Versão do programa computacional Assistat para 0 sistema operacional Windows. Revista Brasileira de Produtos Agroindustriais 4: 71-78.

Soares, M.B.P., Brustolim, D., Santos, L.A., Bellintani, M.C., Paiva, F.P., Ribeiro, Y.M., Tomassini, T.C.B., Santos, R.R. 2006. Physalins B, F and G, secosteroids purified from Physalis angulata L., inhibit lymphocyte function and allogeneic transplant rejection. International Immunopharmacology 6: 408-414. 
Souza, H.A., Pio, R., Chagas, E.A., Reis, J.M.R., Rodrigues, H.C.A., Ramos, J.D., Mendonça, V. 2007. Doses de nitrogênio e fósforo na formação de mudas de tamarindo. Bioscience Journal 23: 59-64.

Taiz, L., Zeiger, E. 2010. Plant Physiology. $5^{\text {th }}$. Sinaver Associetes, Sunderland, EUA. 782p.

Teixeira, I.R., Kikuti, H., Borém, A. 2008. Crescimento e produtividade de algodoeiro submetido a cloreto de mepiquat e doses de nitrogênio. Bragantia 67: 891-897.

Tomassini, T.C.B., Barbi, N.S., Ribeiro, I.M., Xavier, D.C.D. 2000. Gênero Physalis - uma revisão sobre vitaesteróides. Química Nova 23: 47-57.

Veasey, E.A., Piotto, F.A., Nascimento, W.F., Rodrigues, J.F., Mezette, T.F., Borges, A., Biguzzi, F.A., Santos, F.R.C., Sobierajski, G.R., Recchia, G.H., Mistro, J.C. 2011 . Processos evolutivos e a origem das plantas cultivadas. Ciência Rural 41: 1218-1228.

Whitson, M. 2012. Calliphysalis (Solanaceae): a new genus from Southeastern USA. Rhodora 114: 133-147. 